\title{
Archipel
}

ARCHIPEL Études interdisciplinaires sur le monde insulindien

$96 \mid 2018$

Varia

\section{Nature Conservation in a Frontier Region of Java during the Colonial and Early Post-Colonial Periods}

Protection de la nature dans une région périphérique de Java au cours des périodes coloniale et post-coloniale

\section{Nawiyanto}

\section{OpenEdition}

\section{Journals}

Electronic version

URL: http://journals.openedition.org/archipel/827

DOI: $10.4000 /$ archipel.827

ISSN: 2104-3655

\section{Publisher}

Association Archipel

\section{Printed version}

Date of publication: 15 November 2018

Number of pages: 129-160

ISBN: 978-2-910513-80-1

ISSN: 0044-8613

\section{Electronic reference}

Nawiyanto, « Nature Conservation in a Frontier Region of Java during the Colonial and Early PostColonial Periods », Archipel [Online], 96 | 2018, Online since 20 November 2018, connection on 24 November 2020. URL : http://journals.openedition.org/archipel/827 ; DOI : https://doi.org/10.4000/ archipel.827 


\section{Nature Conservation in a Frontier Region of Java during the Colonial and Early Post-Colonial Periods}

\section{Introduction}

The concern for environmental protection in Indonesia is not new. The later decades of nineteenth century Java saw the adoption of conservation policy ${ }^{2}$. The underlying force behind the concern was the idea that special measures needed to be taken to protect the wealth of the Indies environment from irreparable losses and long-term deterioration resulting from demographic and socio-economic processes. This development had features that set themselves clearly apart from the longstanding measures that reserved parts of the environment for power-holders. The conservationists believed that the importance of nature protection was not only linked to economic values, but scientific, aesthetic, and moralistic ones as well. ${ }^{3}$

The conservation movement in the Netherlands Indies was part of a broader phenomenon emerging as a response to the ongoing deterioration of nature and wildlife occurring on other continents. ${ }^{4}$ With origins in Euro-American thought, conservationist ideas spread and were adopted in colonial policies through the agency of botanists and other natural scientists, who with their long-standing scientific networks, were able to generate a sense of environmental crisis. ${ }^{5}$ The

1. Department of History, Faculty of Cultural Science, University of Jember, East Java, Indonesia.

2. Boomgaard 1999, p. 264.

3. Dammerman 1929, pp. 21-22; Westermann 1945, p. 417.

4. Westermann 1945, p. 417; Mo 1957, pp. 160-161.

5. Grove 1995, pp. 484-485; Grove et al. 1998, p. 16. 


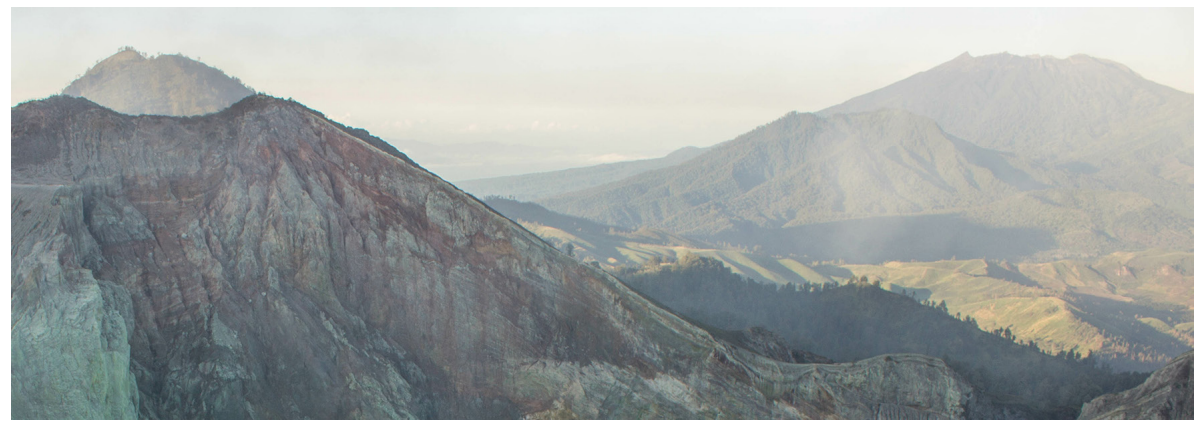

Fig. 1 - Mountainous Landscape of the Besuki Region (Photog.: Nawiyanto 2018)

growing sense of environmental crisis led to the emergence of an awareness of the need for conservation. Emerging as state business, the conservation measures represented what conservationists thought to be good for the interests of the people, but often not in the same ways as the people did themselves. Consequently, conservation projects were also a subject of contest over wealth and power, especially between the state and the people. ${ }^{6}$

This article aims at examining the development of nature conservation in the Residency of Besuki. This residency was situated in Java's Eastern Salient and during most of its existence, it consisted of four regencies: Panarukan (later, Situbondo), Bondowoso, Jember, and Banyuwangi. This region was often referred to as the Oosthoek during the Dutch colonial period, and long constituted a contested political frontier among major centres of political power in Java and Bali. ${ }^{7}$ After obtaining the region in 1743 from the Susuhunan Pakubuwana II of Surakarta, ${ }^{8}$ the Dutch officially established the Residency of Besuki in 1814 and its definitive administrative territory was acquired in 1882 with the incorporation of Banyuwangi Regency. ${ }^{9}$

The region of Besuki has a mountainous landscape. Tomé Pires describes it as a mountainous country. ${ }^{10}$ In the northwest of the region, the Hyang Mountains - with the extinct Argapuro volcano soaring at their apex - stretch from Probolinggo to northern Jember. To the northeast, the Hyang Mountains are connected with the Ringgit volcano in Panarukan. In the northeast lie the Ijen Mountains with the soaring Raung and Merapi volcanoes, described by L. van Vuuren as "one of the most remarkable volcanic areas in the world."

6. Peluso 1992.

7. Sri Margana 2012.

8. Lombard 1996, vol. 3, p. 46; Ricklefs 1998, p. 306.

9. Cribb 2000, p. 125.

10. Cortesão 1967, vol. I, p. 198.

11. Van Vuuren 1929, p. 14. 
The slopes of the region's two mountain ranges merge and form the Bondowoso highlands, while in the south, the range of Watangan, Mandiku, Meru and Betiri hills separates the lowland of Jember from Banyuwangi. ${ }^{12}$

Another striking element to the environment of Besuki was forest. Tombe, a French ship captain traveling by land from the north coast of Banyuwangi to Surabaya, reported in 1805 that the route still took the form of footpaths running through jungles. ${ }^{13}$ The largest part of Besuki forest was categorized as non-teak forest. ${ }^{14}$ Rather than being covered by rainforest vegetation as found in the western part of Java, Besuki is characterised by a predominantly monsoon forest. Donner classifies it as deciduous monsoon forest, naturally developing in areas with small quantities of rainfall and a prolonged dry season. Compared with many other parts of Java, Besuki has less rainfall and a seasonally dry climate. ${ }^{15}$ In a broader context, the vegetation of the Besuki region reflects a trend of decreasing rainfall from west to east across the island of Java. ${ }^{16}$

There are two main rivers that cut across the Besuki region. Originating in the Hyang Mountains, Kali Sampean flows north to the Madura Strait at Tanjung Pacinan through the Bondowoso and Panarukan regencies. Meanwhile, Kali Bedadung emerges from several streams that flow south from the Hyang and the Ijen Mountains, and passes through the Jember regency to the Indian Ocean in the Puger district. ${ }^{17}$ A number of small streams also flow to the surrounding seas in a different direction. Kali Banyuputih flows from the Ijen Mountains to Panarukan before entering the strait of Madura. Kali Mayang originates in the Ijen Mountains and flows to the ocean after merging with Kali Ambulu and Kali Sanen. With their springs in the Ijen Mountains, Kali Baru cuts across the area of Banyuwangi and flows to the Indian Ocean, whereas Kali Setail flows to the Bali Straits. ${ }^{18}$ These rivers and streams formed fertile alluvial soils by bringing mud and volcanic materials in valleys and coastal plains.

Mostly consisting of young volcanic soils, Besuki generally has good soils as one major foundation for agriculture. The region's population engaged in both irrigated field (sawah) and dry field (tegalan) cultivations. On irrigated fields different crops could be grown throughout the year. Rice was the most important food crop. During the dry season, secondary food crops (palawija) were also grown on irrigated lands. Dry fields, by contrast, were characterised by the absence of irrigation and were closely linked to crops that call for less water, including maize, cassava, vegetables, and later also tobacco. Apart from smallholder agriculture, in

\footnotetext{
12. Veth 1903, pp. $572-577$.

13. Lombard 1983, p. 264.

14. Poerwokoesoemo 1956, p. 35.

15. Whitten, Soeriaatmadja and Afiff 1996, p. 122.

16. Donner 1987, pp. 106-107.

17. Hageman 1868, pp. 252-253, 280-281.

18. Schulze 1890, pp. 286-287.
} 
the region of Besuki there was also plantation agriculture developed by European plantation enterprises. This sector began to develop from the 1830s onwards and has rapidly expanded since the $1870 \mathrm{~s}$. A variety of export-oriented estate cropsespecially coffee, sugar, tobacco, and rubber - were cultivated and have altered the natural environment of the Besuki region.

The choice to focus on the Besuki Residency was made because the region showed a strikingly contrastive feature, in environmental and socio-economic terms. On the one hand, the region had the largest conservation areas on the island of Java during the colonial and post-colonial eras. On the other hand, it experienced great transformations especially from around 1870 . As a result, in 1912 Besuki was described as "an emerging region." ${ }^{19}$ It shifted from one of sparse population - the least densely populated in the whole of Java- to a more densely populated area. Between 1890 and 1930, for example, the population density of Besuki increased by $125 \%$, whereas the population density of Java only increased by $70 \%{ }^{20}$ From an economically minor region, Besuki was also transformed into a leading centre of agricultural production. Besuki was among the three highest-producing places in the Netherlands Indies for export tobacco. During 1926-1930, for example, $25 \%$ of tobacco exports from Java originated in Besuki, while the region constituted only $7.5 \%$ of Java's total land surface. ${ }^{21}$

These two contrasting features indicated that Besuki's natural environment was increasingly pushed back by socio-economic transformations. There was a growing concern about the increasing risk of irreversible natural loss that required immediate response and action. Nature conservation in Besuki reflected the implementation of policy adopted by the government through a centralized means, without taking the local people's interests into consideration. It is argued that there was a continuity between colonial and early post-colonial nature conservation. Nature conservation was very much part of government circles, accommodating mostly the Europeans during the colonial period and Indonesian officials during the post-colonial one. Challenges to nature conservation were not only due to the continuing contests over resources between the state and the people, but also to internal issues within the government itself. The policies and problems existing in the implementation of nature conservation both during the colonial and postcolonial periods seem to have remained much unchanged.

\section{Short Historiographical Survey}

Studies of nature conservation in Indonesia have been produced by scholars with various backgrounds, both natural and social scientists. Early works came mainly from natural scientists especially botanists, zoologists, and foresters.

19. Broersma 1912.

20. Boomgaard and Gooszen 1991, pp. 217-218.

21. Clemens, Lindblad and Touwen 1992, p. 63; Boomgaard and Gooszen 1991, p. 217. 
More recently, there have been a growing number of works on the subject by anthropologists, historians, and other social scientists. With their varying backgrounds, scholars on nature conservation in Indonesia approach the subject in different ways. For the purpose of our discussion, it might be useful to broadly categorize the existing literature into two major approaches: nation-wide policy approach and case-study/regional conservation practice approach.

Many works dealing with nature conservation in Indonesia employ a nation-wide policy approach. Most of them argue that nature conservation is desirable, even if it is at the expense of the people's direct interests. In their view, nature conservation is vital not only for economic values but scientific and aesthetic ones as well, and all these values should be preserved for the interest of future generations too. ${ }^{22}$ Uncontrolled forms of natural resource use is regarded as bringing on changes that could cause irreparable damage to nature's original state and environmental crisis. ${ }^{23}$ They also develop the argument that the making of colonial conservation policy and the promulgation of conservation regulations were necessary and constituted significant progress in preventing the presence of human activities. ${ }^{24}$ Some authors argue that the process was inseparable from the involvement of particular individuals, groups and interests, bringing all issues related to nature conservation into the political agenda and policy-making process. ${ }^{25}$

Many of the early nation-wide policy oriented conservation publications have largely focused on conservation during the Dutch colonial era, partly due to the fact that they were produced during the colonial era. Consequently, little is known about nature conservation during the early decades following independence. One important exception is Arnscheidt's work presenting a discourse analysis of nature conservation in Indonesia as manifested in policy, law and practice with a long-term time perspective from the pre-colonial period to the present. ${ }^{26}$ But most authors, including Arnscheidt, have not taken a full look at the regional dynamics of nature conservation implementation. This shortcoming is also found in literature appearing in the post-colonial era that looks at nature conservation from a broad, nation-wide perspective. ${ }^{27}$ Without going into further detail, some merely cursory remarks have indicated that conservation measures were not easy to implement in the field and the outcomes often did not materialize as expected. ${ }^{28}$

22. Dammerman 1929; Steenis 1939; Westermann 1945; Lught 1933.

23. Eshuis 1939; Dammerman 1929.

24. Dammerman 1929; Sandbergen 1932; Kiès 1936; Eshuis 1939; Hoogerwerf 1953.

25. Westermann 1945; Boomgaard 1999; Cribb 1988, 1997; Yudistira 2014.

26. Arnscheidt 2009.

27. Situmorang 2013; Groves 1977; Yuwono 2013.

28. Hoogerwerf 1954; Schuitemaker 1950. 
An abundant literature representing a case-study/regional conservation practice approach has been produced on the basis of field observations or site visits to the nature and wildlife reserves. Part of the writings come from the Dutch colonial period, for example on Hyang Highlands, Poerwo, and Baluran. ${ }^{29}$ The writings usually contain a report on the state of the visited reserves regarding the populations of plant and wild game species in the protected area they visited. Based on their observations, recommendations have been on how to improve the management of the nature and wildlife reserves. More conservation literature in the second group restricts the discussion to the New Order and Reform eras. Many have argued that there is a contestation between the interests of local people and conservationists leading to the destruction of protected areas. ${ }^{30}$ Focusing too much on more recent periods can easily lead to the misconception that nature conservation in post-colonial Indonesia only emerged as an issue during the New Order era, as if nothing had happened in the field during earlier decades.

Three major shortcomings prevail in the existing nature conservation literature. One is a neglect of the importance of the early decades of the independence era in the development of nature conservation due to excessive focus on the New Order and Reform eras. Another major shortcoming is a lack of accounts of the regional dynamics of nature conservation implementation during the colonial and early post-colonial periods. There is a strong impression that the early two decades of the independence era, which have also often been called the decolonization period, form a hiatus in the historiography of nature conservation in Indonesia. Therefore, the present article seeks to bridge the gap in our knowledge in these issues by discussing nature conservation in the region of Besuki during the colonial and early post-colonial periods. This will be done through a combined analysis of nature conservation policy and regulations, and the implementation of conservation measures in the form of nature reserves in the region. The aim is to offer new insight into what occurred and has changed or remained the same in nature-conservation practice between the two periods under consideration, generally thought of as strikingly different in political and social terms, but perhaps, as may be shown, much less so in conservation terms.

\section{Method}

This article draws upon a great variety of historical source materials. The primary sources include archival materials, official and private organisation publications, and contemporaneous newspapers. Among the archival materials figure memoranda of transfer of duties (Memories van Overgave, 1913-1938)

29. Groneman 1902; Ledeboer 1934; Appelman 1939.

30. For example Myers and Muhajir 2015; Siburian 2008, 2010; Hoogerwerf 1974; Kadri et al. $1981 / 1982$. 
written by Residents of Besuki during their period of administration. Some of these memoranda have been translated and published as Memori Serah Jabatan 1921-1930 (ANRI 1978) and Kenang-Kenangan Pangreh Praja Belanda 1920 (Wal 2001). Other archival materials include General Secretariat (Algemeene Secretarie, 1919-1920). Most archival materials were obtained from the National Archives of the Republic of Indonesia (ANRI), Jakarta.

A number of official and private organisation publications originate from various places. There are valuable materials from the National Library of the Republic of Indonesia (PNRI) in Jakarta, including: Annual Reports of the Forestry Service (Verslagen van den Dienst van het Boschwezen), private organisation reports produced by the Netherlands Indies Society for the Protection of Nature, which provide useful information relating to conservation issues. Also from this library, most contemporaneous newspapers and magazines were also examined, including Trompet Masjarakat and Malang Post newspapers. A number of organisational publications provide quite specific information. Valuable publications for the discussion of forest and nature protection include Tectona (later, Rimba Indonesia), Tropische Natuur (later, Penggemar Alam), and Gema Perhutani. Part of these publications are kept in the Library of the Faculty of Forestry, Gadjah Mada University, Yogyakarta. A valuable guidebook for the region's natural environment is The Ecology of Java and Bali produced by Tony Whitten et al. (1996). There are also a number of unpublished reports kept in the library of Balai Konservasi Sumber Daya Alam (Jember).

\section{Nature Conservation and its regulations}

The early conservation approach in Netherlands Indies, including Besuki, was closely connected with the economic interests in agriculture. The connection could easily be seen from the expected outcomes of the conservation regulations. The Government Decree (Gouvernementsbesluit) of 1873 and the Clearance Ordinance (Ontginningsordonnantie) of 1874 required both Europeans and locals running agricultural operations on sloping areas to take anti-erosion measures. This stipulation primarily rested on the idea that upland agricultural outputs were in decline due to the washing away of fertile soils following the removal of forest cover. ${ }^{31}$ Terracing was encouraged in order to protect soils and to maintain agricultural production, a measure highly recommended in Java by K. F. Holle, an agriculture expert working in the colonial administration. Informed by the agriculture-induced soil fertility destruction in the United States of America, Holle was the first (in 1866) to warn about the danger of erosion. ${ }^{32}$

31. Donner 1987, p. 120.

32. Holle 1866, pp. 122-131. 
More significant progress in conservation was reflected in the 1884 Forest Ordinance, stipulating the preservation of watershed-protecting forests. According to this ordinance, no tree felling was allowed in montane forest above 4,000 feet in Eastern and Central Java. ${ }^{33}$ The underlying idea in this stipulation was to protect water catchment areas, a sensible action advocated earlier by the German naturalist Franz Junghuhn on Java around the midnineteenth century. ${ }^{34}$ This stipulation was closely linked to the sponge theory, suggesting that forest cover was the best regulator of water regimes. ${ }^{35}$ Uncontrolled agricultural expansion towards montane peaks was seen as a serious threat to the very existence of agriculture as it would seriously affect water flows and irrigation supply. Therefore, for the sake of agricultural sustainability, such expansion should be stopped.

It came as no surprise that strong proponents of watershed forest protection were found among engineers working in the colonial irrigation service. ${ }^{36}$ Some support also came from a number of officials at the Forest Service such as J.W.H. Cordes, S.P. Ham, A. de Jong and G.S. de Graaf. ${ }^{37}$ Between 1915 and 1930 there had been a wide debate among Dutch scientists concerning the hydrological values of montane forest. Despite the inconclusive scientific evidence, the proponents of the sponge theory won over the other group of scientists putting forward the idea that hydrological regimes were a function of geological formations and soil properties. Since then the sponge theory has shaped forest policy regarding natural forest management, and only quite recently has its scientific validity come under attack again. ${ }^{38}$

In the Besuki region, protecting the water catchment forest area was also a major issue, given the region's mountainous landscape and expanding agricultural operations. A.J.M. Ledeboer stated that the existence of 13 sugar industries in Besuki and Probolinggo, rice fields in Kraksaan and Bondowoso and all rice fields in Jember, which were also used for estate tobacco cultivation, depended for their irrigation on water originating from the Hyang Highlands. ${ }^{39}$ As elsewhere in the Netherlands Indies, the activities of shifting cultivation (ladang) were regarded by the colonial authority in Besuki as a major threat to the hydrology-regulating montane forest. ${ }^{40}$ In order to protect water catchment

33. Boomgaard 1999, p. 262.

34. Cribb 1988, p. 10; Steenis 1972, p. 4.

35. Potter 2003, p. 38.

36. Boomgaard 1996, p. 21.

37. Goor and Kartasubrata 1982, pp. 528-529.

38. Smiet 1990, p. 298; Smiet 1987, pp. 156-157.

39. Ledeboer 1934, pp. 5-6.

40. ANRI, MvO Besuki, 1931-1934. 


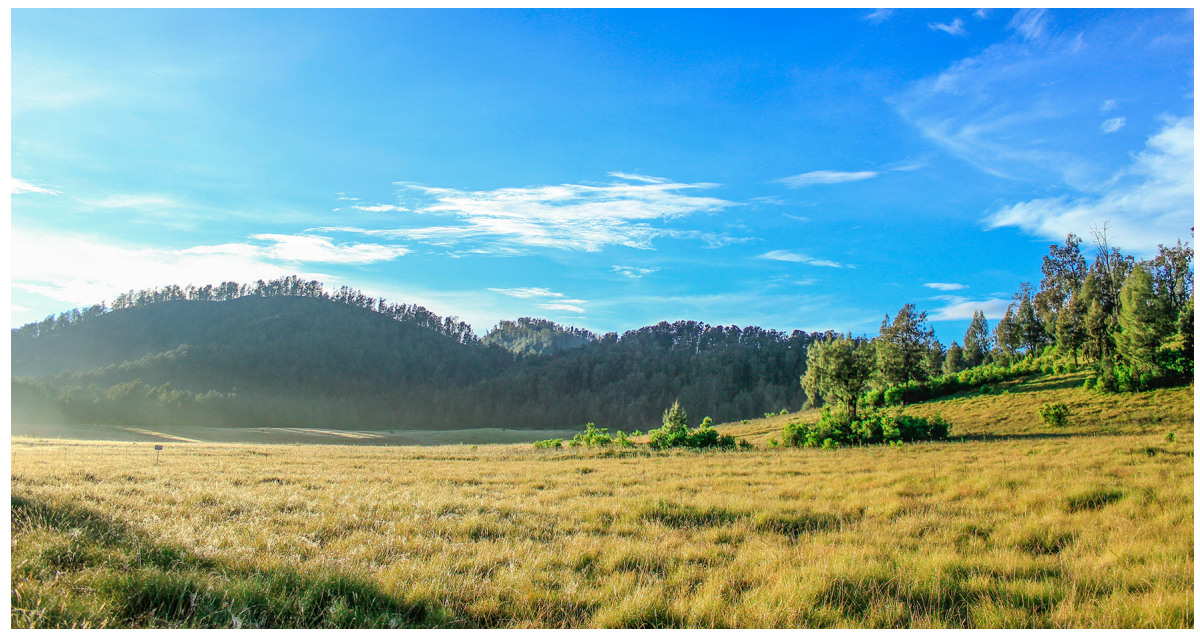

Fig. 2 - Hyang Highlands, Argapuro (Photog.: Nawiyanto 2018)

areas, forest clearing in the Hyang mountain complex was prohibited from 1913 and from 1922 long leases (erfpacht) of land for mountain estates were no longer granted. ${ }^{41}$

Around 1900, a new trend also developed in the conservation movement. It aimed at protecting wild fauna, flora and natural landscapes. The primary reasons were their aesthetic and scientific values. ${ }^{42}$ The concerns about wild fauna protection were greatly motivated by the commercial hunting of birds of paradise on the outer islands of the Archipelago, ${ }^{43}$ and of other species such as rhinoceros and wild ox on the densely populated island of Java. The concerns were voiced among others by P.J. van Houten and M.C. Piepers in the 1890 s. $^{44}$ In the Besuki Residency, the Ledeboer brothers were particularly concerned with the alarming decline in the population of deer in the Hyang Highlands. ${ }^{45}$ The first legal achievement was the enactment of the Protection of Wildlife Ordinance (1909), providing protection for all wild animals, except the harmful ones. ${ }^{46}$

The 1910s saw significant progress in the conservation movement. There were two major events which marked this decade. In 1912 the first organisation dealing with nature conservation, the Netherlands Indies Association for Nature

41. OMV 1908; ANRI 1978, p. xixc.

42. Dammerman 1929, p. 1; Broersma 1937, p. 228.

43. Cribb 1997, pp. 379-408.

44. Piepers 1896, pp. 38-42; Cribb 1997, p. 3; Boomgaard 1999, p. 264.

45. Franck 1937, p. 34.

46. Sandbergen 1932, p. 439; Kiès 1936, p. 13. 


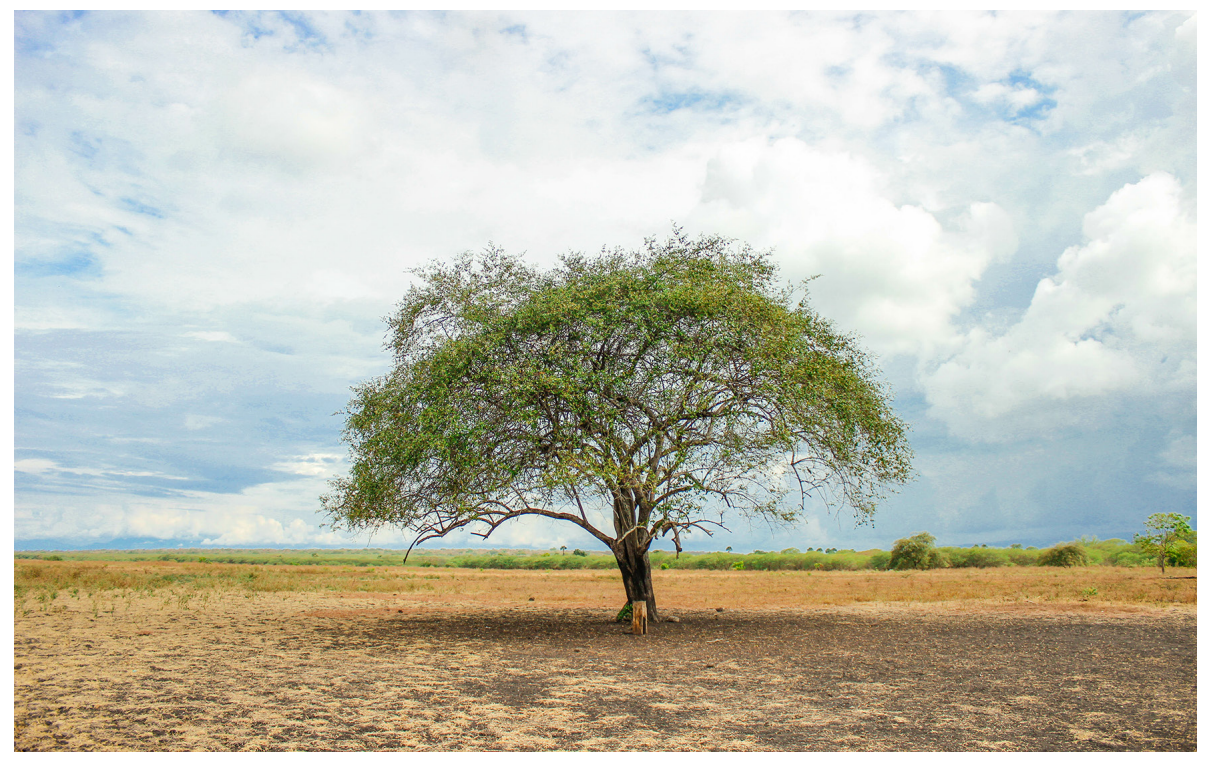

Fig. 3 - Baluran Nature Reserve (Photog.: Nawiyanto 2018)

Protection (Nederlandsch-Indische Vereeniging tot Natuurbescherming), was established, with forester botanist Sijfert Hendrick Koorders as its chairman. ${ }^{47}$ Significant achievements in the field of conservation matters, both in legal and practical terms, can be credited to this association. ${ }^{48}$ The second significant event was the enactment of the Protection of Natural Wealth Regulation in the Netherlands Indies (1916), governing the creation of nature monuments. ${ }^{49}$ In Besuki this regulation provided a legal basis for nine nature conservation areas established in 1919 and 1920. With the exception of authorized scientific purposes, any form of human intervention in these areas - such as collecting botanical specimens, hunting wild animals, setting fires, and herding livestock - was completely prohibited..$^{50}$

The idea behind the prohibition was a belief that human activities in such areas would bring changes and could cause damage to the original state of nature, which was considered very valuable and to be preserved for scientific or aesthetic reasons. An important improvement was the enactment of the Natuurmonumenten- en Wildreservaten-ordonnantie (Nature Monuments

47. Steenis 1939, p. 150.

48. Eshuis 1939, p. 292.

49. Pluygers 1952, pp. 40-41.

50. Dammerman 1929, pp. 67-68; Eshuis 1939, p. 299. 
and Wildlife Reserve Ordinance) in 1932. ${ }^{51}$ Under the new ordinance human intervention was tolerated to a certain degree, especially for the sake of habitat management. This ordinance facilitated the establishment of an extensive wildlife reserve. In Besuki the result was the establishment of the Baluran wildlife reserve in 1937, based on the Governor General's Decree dated 25 September 1937, No. 9 (Stbl./1937/No. 544). ${ }^{52}$

Several regulations were issued as regards wild game protection. This development partly resulted from external pressures, especially from Britain and North America as the major destinations for the animal-products trade from the Netherlands Indies. ${ }^{53}$ The market of animal products for export was made up of bird feathers, crocodile skins, tiger skins, rhino horns, ivory, turtle eggs, and various animal specimens, for example. ${ }^{54}$ The result was the Game Protection and Hunting Ordinance (Dierenbescherming-en Jachtordonnantie) of 1924. Applied only in Java and Madura, this regulation contains stipulations regarding the introduction of a hunting season restricted to a certain period of time, the requirement of a hunting license obtained from the authorities for a fee, and the list of animal species under protection..$^{55}$ This regulation was revised through the Game Protection Regulation and Hunting Ordinance of 1931. Apart from individually listing protected animals in the Netherlands Indies, a new provision stipulates a total ban on the trade of dead and living protected animals, as protection was ineffective without export prohibition. ${ }^{56}$ In order to overcome problems linked to the various regulations from one locality to another, the following year, the 1931 ordinance was extended to the whole Archipelago..$^{57}$

In Besuki, hunting activities were subject to a set of rules and conditions. Hunters were required to equip themselves with the appropriate legal documents issued by the colonial authorities and they had to undertake their activity only during the designated period. It was reported that 86 hunting permits and 214 hunting licenses were issued by the authorities in Besuki in 1934. ${ }^{58}$ Other regulations were also occasionally enforced. The hunting of wild ox, deer, and antelope was prohibited in 1937 and $1938 .{ }^{59}$ In general, the primary reason behind such measures was to give sufficient time to the species

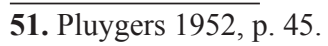

52. Hoogerwerf 1948, pp. 33-35; Sedhana 1982, p. 4.

53. Dammerman 1929.

54. Yuwono 2013, pp. 130-149; MacKinnon 1986, p. 263.

55. Kiès 1936, p. 18.

56. Appelman and Endert 1936, pp. 176-177.

57. Kiès 1936, p. 18.

58. Hoogerwerf and Steenis 1935, pp. 78-79.

59. Rengers Hora Siccama 1940, p. 85. 
to rejuvenate their populations. In order to increase big game populations ${ }^{60}$ in 1941 , on the basis of his observations in the forest of Banyuwangi, L. Berczy urged the government to provide a bounty on wild dogs (ajak).$^{61} \mathrm{He}$ believed that the declining number of big game populations was caused by the excessive number of wild dogs and that the adoption of the bounty system would draw more people to get involved in the extermination of this predator.

Despite broadening conservation ideas during the Dutch colonial period, the entire conservation movement had one major constant. The movement was still confined to government circles, rather than involving ordinary people. This feature was reflected in the fact that for the entire period of its existence, members of the Netherlands Indies Association for Nature Protection were almost exclusively Europeans, with a few local aristocrats. ${ }^{62}$ Its membership was a mixture of people with different backgrounds, such as professional naturalists working in public services, ordinary nature lovers, and estate owners/hunters.

The chairman of the association, S.H. Koorders (1863-1902), was born in Bandung. After obtaining degrees in natural science, botany and forestry in the Netherlands and Germany, he went to the Netherlands Indies in 1884. He worked for 12 years for the Dutch government and was posted in various locations: Bogor Botanic Gardens, the forest districts of Jepara, Semarang, Probolinggo-Besuki and to Bogor Herbarium. There Koorders researched plants in Java and other parts of the Archipelago. He pursued a doctoral program at Bonn University and obtained his degree in 1897. In 1903 Koorders returned to the Netherlands Indies and was appointed as head of the forest district of Bagelen, Purworejo. Concerned about the damage inflicted upon nature by human activities related to the use of forest resources, Koorders took the initiative to set up the Netherlands Indies Association for Nature Protection in 1912 and acted as its chairman until his death in 1919. ${ }^{63}$

Planters on larges estates from the Besuki region were also members of the association, including Teun Ottolander and A.J.M. Ledeboer. Teun Ottolander (1854-1935), was born in Boskoop, the Netherlands. He started his career as an assistant on chicona and coffee estates in Central Java in 1879 and was later promoted to estate manager in East Java. In 1909 he established a coffee plantation in Tamansari Banyuwangi. Apart from being a planter, Ottolander once served as the president of the Netherlands Indies Agricultural Syndicate. $\mathrm{He}$ also had a strong interest in nature protection and collected plants in the region of Besuki, for example in Bayulor (1901), Pancur (1901), Raung-Ijen (1902), and Prajekan-Situbondo (1908). Since 1903 Ottolander had preserved a plot of forest which was the habitat of rare plant species on his estate in the Raung

60. Mo 1957, pp. 171-172.

61. Berczy 1941, p. 243.

62. Pluygers 1952, p. 45.

63. Yudistira 2014, pp. 6-15. 


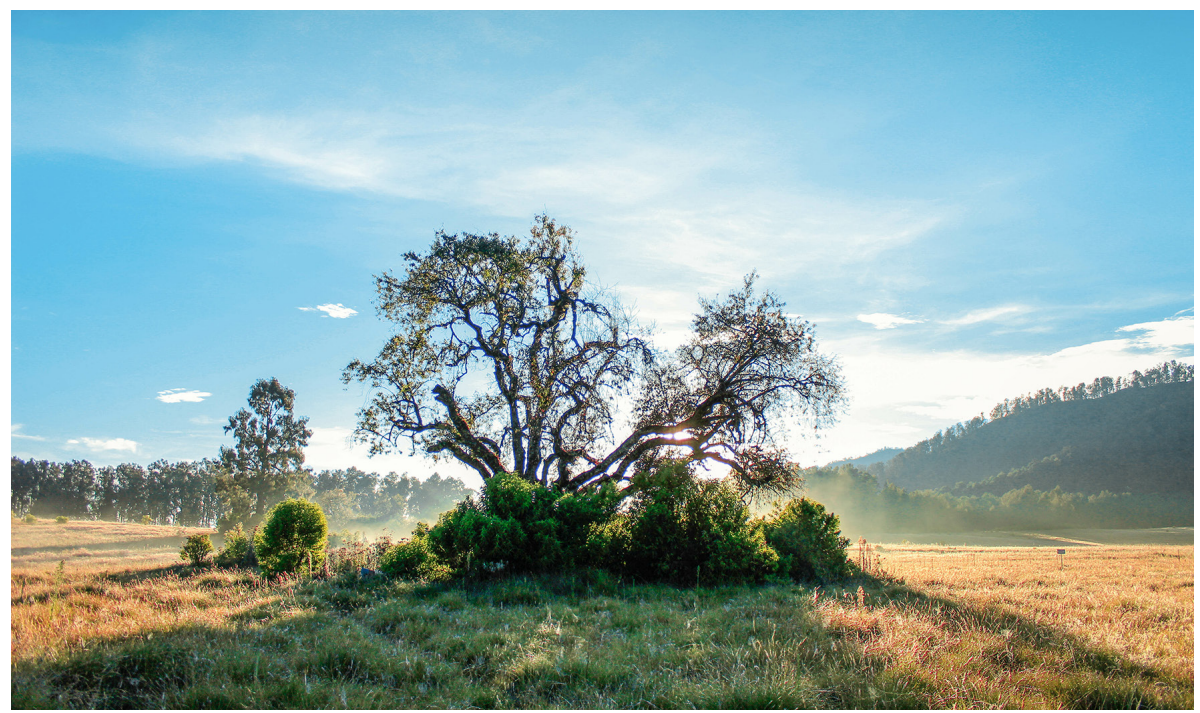

Fig. 4 - Hyang Highlands, Argapuro (Photog.: Nawiyanto 2018)

Mountains. ${ }^{64}$ A.J.M. Ledeboer and his brother, B. Ledeboer, were passionate big-game hunters and estate owners. A.J.M. Ledeboer in particular was known as a fanatical tiger hunter. He claimed to have killed around 100 Javan tigers between 1910 and 1940. He lived in Wadung, near Glenmore, Banyuwangi. The Ledeboer brothers recorded good achievements in protecting deer populations in the Hyang Highlands by adopting strict and systematic measures and were thus successful in reviving the Hyang Highlands as a deer paradise. ${ }^{65}$

Nature conservation appears never to have attracted special interest from the nationalist movement, although its significance was not denied. The local representatives in the Council of the People (Volksraad) certainly endorsed that body's unanimous vote to urge the government to establish more wildlife reserves and to strictly prohibit the hunting and trading of certain wild game species and their products. ${ }^{66}$ But among the nationalist organisations, including those with popular support in Besuki, conservation issues were hardly voiced. The major focus of their concerns was more socio-economic and political in nature.

During the early decades of the independence era, the need for nature conservation was raised by a number of figures. A few of them were European conservationists who stayed on in Indonesia. A leading figure was Andries Hoogerwerf, a Dutch naturalist and conservationist who worked at the Bogor

64. Hoogerwerf and Steenis 1935, pp. 79-80; Koning 1928, pp. 104-106.

65. Kiès 1936, p. 16.

66. Kiès 1936, p. 16; Westermann 1945, p. 420. 
Botanical Gardens until 1957. Hoogerwerf was the Head of the Division of Nature Protection and Hunting, Bogor Botanical Gardens. He was perhaps the most productive author publishing articles on nature and wildlife conservation in the 1950s (Hoogerwerf 1953; Hoogerwerf 1954; Hoogerwerf 1974). A growing number of Indonesians also appeared in the conservation movement. A notable name was Soepardi, an Indonesian forester, who worked for the Forest Planology Section and who wrote valuable books on the forests of Java in the 1950s. Other important figures were Koesnoto Setijodiwirijo and Koesnadi Partosatmoko. Setijodiwirijo was the Director of the Bogor Botanical Gardens. ${ }^{67}$

Apart from the worsening condition of the natural environment during the 1940 s, the sense of crisis and the urgent need for nature conservation were also raised by international networks of organisations, as well as growing interest in conservation issues in many countries. During its congress held in Brussels in 1950, the International Union for Nature Protection and Natural Resources (IUCN) expressed growing concerns about the status of threatened species to the Indonesian government. The following visit to Indonesia of the vice-president of the organisation, H.J. Coolidge, who also represented the Pacific Science Association and Standing Committee on Pacific Conservation, increased the global concerns about the alarming situation of particular wild game species in the country. ${ }^{68}$ The push grew stronger around the mid-1960s, after the IUCN launched its South East Asia Conservation Project, formulated in its meeting held in Nairobi in $1963 .{ }^{69}$

To show its commitment to conservation matters, Indonesia joined the International Union for Nature Protection in 1954, and its membership was represented by the Central Institute for Nature Research of the Indonesian Botanic Gardens (Bogor). ${ }^{70}$ This was followed by the enactment of conservation regulations, mostly inherited from the Dutch era. The Nature Protection Ordinance of 1941 was readopted after independence, based on the Decree of the Minister of Agriculture and Agrarian Affairs No. 110/ Um/1957. The Forest Ordinance of 1967, a revised version of the 1927 and 1932 forest ordinances, provided further legal framework, governing four types of conservation areas: nature reserves, game reserves, hunting reserves, and recreation reserves. ${ }^{71} \mathrm{~A}$ decree by the Minister of Agriculture issued in 1970 extended legal protection - previously given to 36 wild animal species under the Wildlife Protection Regulation of 1931-to another 14 species,

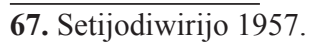

68. Satmoko 1953, pp. 406-407.

69. Talbot and Talbot 1968, p. 15.

70. Setijodiwirijo 1957, p. 7.

71. Nasution 1968, pp. 13, 20; Hutabarat 1972, p. 10; Boer et al. 1978, p. 27. 
reaching a total of 50 wild animal species ${ }^{72}$. Similarly, various regulations concerning hunting permits and licences, restrictions and hunting seasons, were established.

In Besuki, the Dutch-created nature reserves were recognized under the newly established Indonesian state. But the colonial regulations supporting their existence were regarded as no longer valid in an independent state. In order to secure the existing nature reserves, a new legal framework needed to be issued under the national legal system. The regulation governing the Nusa Barung Nature Reserve was renewed with a decree by the Minister of Agrarian Affairs No. 110/VIII/1957. ${ }^{73}$ The Baluran game reserve was legally renewed with the Decree of the Minister of Agriculture and Agrarian Affairs, No. Sk/11/PA/1962. ${ }^{74}$ In the late 1960 s, Commission III of the Forestry Department Workshop, led by Moerdijanto, further proposed to the government to designate the reserve as a national park. ${ }^{75} \mathrm{New}$ regulations were also issued concerning the nomination of the Meru-Betiri forest area as a nature reserve, stipulated in the Decree of the Minister of Agriculture, No. Kep.31/12/'66 and its designation in 1972 as a game reserve by the Decree of the Ministry of Agriculture No. 276/Kpts/Um/6/1972. ${ }^{76}$ Another new regulation was the Decree of the Minister of Agriculture and Agrarian Affairs No. 12/PA/1962, stipulating the creation of the Hyang Highlands game reserve ${ }^{77}$ on territory previously held by the Ledeboer brothers as leased land.

During the early independence period however, the conservation movement remained limited to government circles and lacked mass support. The political parties mushrooming in the 1950s, with all their grass-roots support, never used environmental arguments, but rather adopted socio-political and agrarian issues in their struggle (Trompet Masjarakat, 5 December 1958). The Partai Sarekat Islam Indonesia (PSII), for example, maintained that the roots of political grievances in Jember, Banyuwangi, and Bondowoso were economic pressures stemming from the domination of foreign estates over land resources, supported by federalists and Dutch collaborators working in the bureaucracy. ${ }^{78}$ Although in 1957 nature-lover organisations were established in four places in Java, membership numbers remained low. ${ }^{79}$ No such organisation was found in Besuki, nor did university student-linked conservation organisations exist, partly because no higher-education institution was established in Besuki until

72. Nasution 1971, p. 5.

73. Sastrawidjaja et al. 1986, p. 5.

74. Sedhana 1982, pp. 4-5; Hoogerwerf 1948, pp. 33-34.

75. Sinaga 1970, p. 13.

76. Departemen Kehutanan 1985, p. 5; Groves 1977, p. 17.

77. Santoso et al., n.d., p. 3.

78. Trompet Masjarakat, 10 Feb. 1951.

79. Setijodiwirijo 1957, p. 8 . 


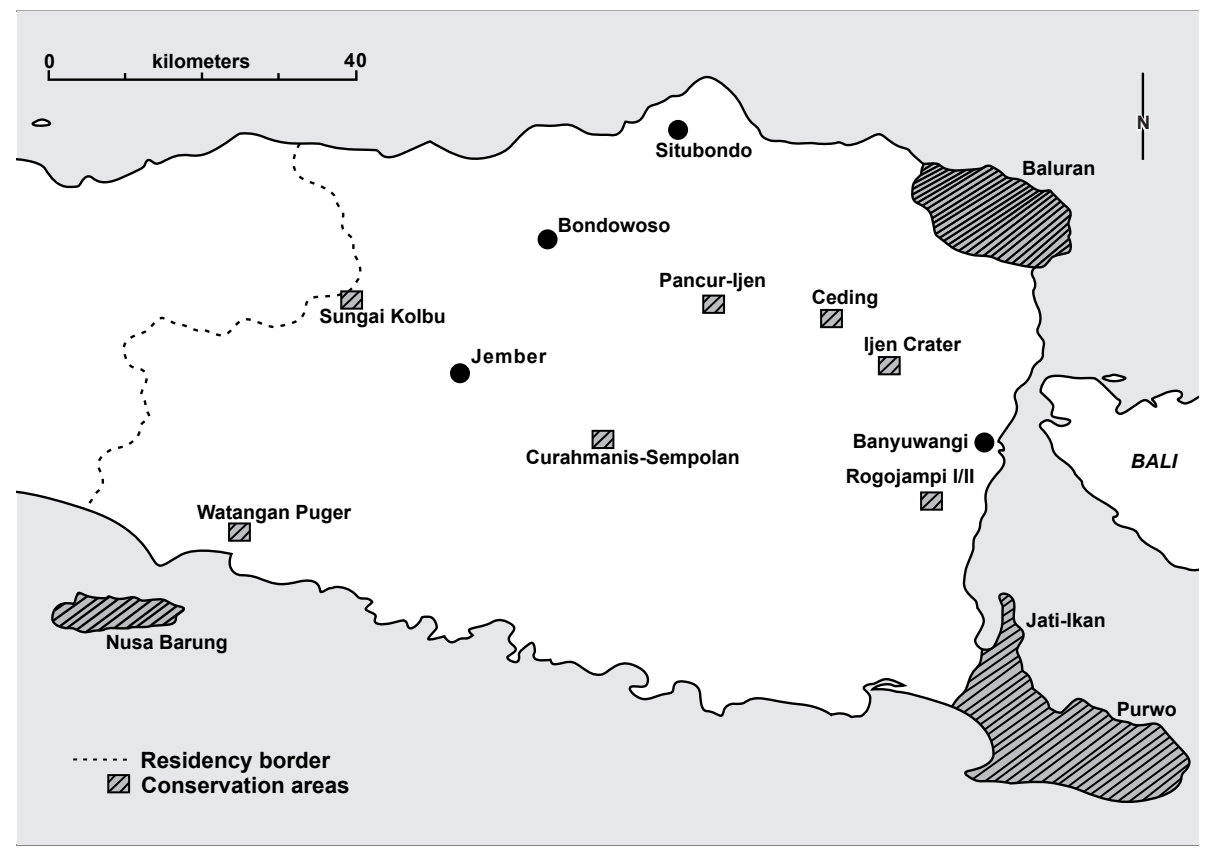

Fig. 5 - Conservation Areas in Besuki (Adapted from Eshuis 1939, p. 302)

around the mid-1960s. Only a few individuals had conservation concerns, and among them were David Hadikesuma, director of the Sukamade Baru estate and Lucas Hadiwinoto, director of the Bande Alit estate (Hoogerwerf 1974; Ted 1974). Their concerns seem to have been nurtured by contact with foreign conservationists who were interested in nature and game protection in the region.

\section{Executing Conservation Measures}

The major conservation measure in colonial Indonesia was the establishment of nature and wildlife reserves. The first conservation areas in Besuki were established in 1919, including Sungai Kolbu (Situbondo), Watangan-Puger I/V, Curahmanis-Sempolan I/VIII (Jember), Rogojampi I/II (Banyuwangi), and Pancur-Ijen I/II (Bondowoso). Altogether they covered an area of around 60 hectares. Five more nature reserves followed in 1920: Ceding and Ijen Crater (Bondowoso regency), Nusa Barung (Jember regency), Jati-Ikan and Purwo or Blambangan (Banyuwangi Regency). In terms of acreage, they were larger than those established a year before, except Ceding. This represented a structural shift from the protection of small, scenic sites to the idea of protecting larger ecosystems. The largest reserve was the Purwo reserve, covering an area of around 40,000 hectares, followed by the Nusa Barung reserve with 


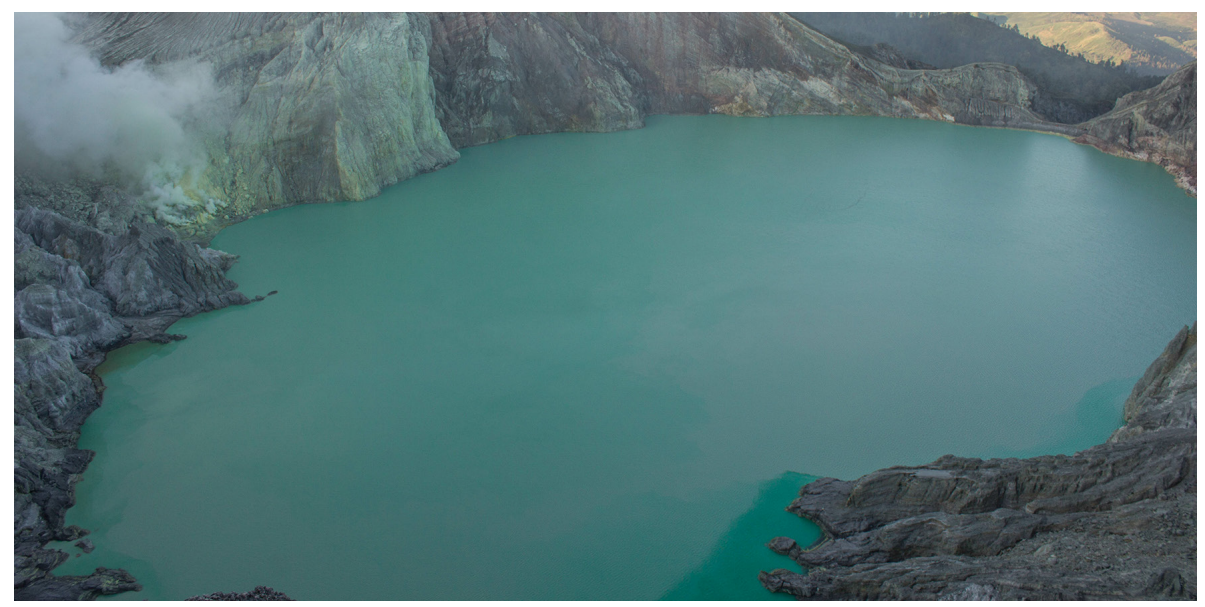

Fig. 6 - Ijen Crater-lake (Photog.: Nawiyanto 2018)

approximately 6,100 hectares. The sizes of the Jati Ikan and Ijen crater reserves were respectively 1,950 hectares and 2,560 hectares. ${ }^{80}$ Another large conservation area was the 25,000-hectare Baluran wildlife reserve established in $1937 .{ }^{81}$ By the end of colonial rule, Besuki had more than 75,000 hectares of conservation areas, the most in Java, whereas in Banten, by comparison, the four conservation areas did not exceed 58,000 hectares. ${ }^{82}$

Each conservation area in Besuki had special values, either aesthetic or scientific, which became the basis for its protection. The reasons behind the protection of the Ceding nature reserve were its travertine basin, with beautiful surroundings built up by microscopic blue algae. The reasons for protecting the Ijen crater included its marvellous greenish-milky coloured crater-lake, volcanic records, and beautiful old casuarina forest. Meanwhile, the Nusa Barung nature reserve was established because the area housed unique insular flora and fauna and in order to keep the reserve in its original state. Also remaining untouched by human activities, the Jati Ikan-Purwo reserve was designated as a sanctuary for the East Java plant and wild animal species. ${ }^{83}$ The 20,000 hectares of savannah west of Purwo were included as part of the reserve in order to strengthen its role in preserving large mammals, and its inclusion was primarily credited to the Dutch forester, F.J. Appelman. ${ }^{84}$

80. ANRI, AlgSec, 83 BT 11 July 1919 and 46 BT 9 Oct. 1920d.

81. Voogd and Rengers Hora Siccama 1939, p. 98; Hoogerwerf 1948, p. 35.

82. Eshuis 1939, p. 305.

83. Dammerman 1929, pp. 30-32, 52-53; Lam 1923, pp. 20-21.

84. Hoogerwerf 1974, p. 19. 
Partly different from the Jati-Ikan-Purwo reserve, the primary reason for the Baluran conservation area was to protect the big game population from extinction. ${ }^{85}$ The underlying reason for the Curahmanis-Sempolan reserve was its richness in flora, considered a representation of the East Java forest ecosystem biodiversity, while its surroundings had been converted into a more homogenous production forest. ${ }^{86}$

Tabl. 1 - List of Nature Reserves in Besuki (Source: Pluygers 1952: Appendix)

\begin{tabular}{|l|l|l|l|l|l|}
\hline No & Name & $\begin{array}{l}\text { Regency } \\
\text { (afdeeling) }\end{array}$ & $\begin{array}{l}\text { Total Area } \\
\text { (ha) }\end{array}$ & $\begin{array}{l}\text { Year of } \\
\text { establishment }\end{array}$ & $\begin{array}{l}\text { Reasons for } \\
\text { establishment }\end{array}$ \\
\hline 1 & Nusa Barung & Jember & 6,100 & 1920 & botany, fauna \\
\hline 2 & Watangan Puger I/V & Jember & 15 & 1919 & botany, prehistory \\
\hline 3 & Ceding & Bondowoso & 2 & 1920 & botany, geology \\
\hline 4 & Sungai Kolbu & Bondowoso & 9 & 1919 & fauna, landscape \\
\hline 5 & Kawah Ijen & Bondowoso & 2,560 & 1920 & $\begin{array}{l}\text { botany, geology, } \\
\text { landscape }\end{array}$ \\
\hline 6 & Baluran & Situbondo & 25,000 & 1937 & fauna \\
\hline 7 & Pancur-Ijen I/II & Banyuwangi & 4 & 1919 & landscape \\
\hline 8 & Rogojampi I/II & Banyuwangi & 25.5 & 1919 & botany, fauna \\
\hline 9 & Jati Ikan-Purwo & Banyuwangi & 62,000 & 1920 & botany, fauna \\
\hline 10 & $\begin{array}{l}\text { Curahmanis-Sem- } \\
\text { polan I/VIII }\end{array}$ & Banyuwangi & 2 & 1919 & fauna \\
\hline
\end{tabular}

The creation of the conservation areas, however, was only part of the larger picture of conservation measures. Another part of the story was their execution in the field, which often presented a more complicated task. The complexity was due to a set of interconnected factors including personnel, equipment, budget, and the social context within which conservation measures were implemented. Conflicts over resource-use often characterized the conservation measures. As the conservation projects were predominantly state-centred initiatives, the emerging conflicts primarily took the form of ruler-versus-ruled. But they were not the only form of conflict. As a matter of fact, conflicts also occurred among state agencies. All these factors seem to have affected the degree to which the conservation measures and desired outcomes could be achieved. In other words, the creation of conservation areas in Besuki and their supporting legal framework were surely an important step towards protecting and preserving wild life and nature. But other things were also of importance, especially the ways in which the conservation projects were managed and supervised.

85. Sinaga 1970, p. 3.

86. Santoso et al., n.d., p. 13. 
In regard to the latter issues, there were intentions that did not materialize as expected. Both internal and external problems were encountered. One of the major internal problems was the lack of officials in charge of carrying out conservation measures. ${ }^{87}$ In Besuki, Resident H.A. Voet reported in 1926 that there were 42 officials working in the region's Forestry Service. ${ }^{88}$ Most of them seem to have worked towards exploitation of the forests rather than its conservation. From 1924 military patrols aided in the supervision tasks, but encroachments on reserves were impossible to prevent because there seem to have been many unpatrolled tiny entrances leading culprits to the protected areas from the sea and along the Asembagus-Banyuwangi road. ${ }^{89}$ In some places, the absence of roads created an extra obstacle for supervision and consequently, violations remained uncontrolled. ${ }^{90}$ In Baluran, the problem was exacerbated by the presence of estate lands in Bajulmati, ${ }^{91}$ which made it easier for intruders to enter the protected area.

Closely linked to the first problem was a lack of budget. The allocated budget for conservation matters in the Netherlands Indies was extremely limited. ${ }^{92}$ In 1931 Appelman lamented that only 8,000 guilders were assigned to nature protection, completely insignificant compared with Belgium's allocation of 0.5 million francs (around 25,000 guilders) or 1 million francs (around 50,000 guilders) allocated for the Albert reserve in the Congo. ${ }^{93}$ Even over the last three years before the Japanese invasion, the total conservation budget in the Netherlands Indies was only 22,000 guilders. ${ }^{94}$ With such a limited budget, there was hardly any proper management or regular supervision undertaken in most conservation areas.

There was certainly a quality problem too. The Resident of Besuki described the enforcement apparatus from the district level downward as incompetent. ${ }^{95}$ Consisting of forest police, district and sub-district heads, and village officials, the major task of the enforcement apparatus was in the field of policing. The task was primarily translated into two main activities: patrolling protected areas and raiding villages suspected of harbouring offenders. ${ }^{96}$ There is little evidence to suggest that propaganda and public education of the villagers were important in preventing conservation offences. Even though such educational

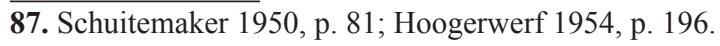

88. ANRI, MvO Besuki: Resident Voet, 1922-1925.

89. Appelman 1937, p. 55.

90. Wijnmaalen 2001, p. 206.

91. ANRI, MvO Besuki, Resident van Romondt, 1935-1938.

92. Hoogerwerf 1974, p. 43.

93. Anonim 1931, p. 481.

94. Coomans de Ruiter 1948-1949, p. 148.

95. ANRI, MvO Besuki, 1931-1934.

96. Meyier 1903, pp. 711-713; Warno 1929, pp. 131-132. 
efforts probably existed, the scale and intensity were certainly not comparable to what was done in the fields of agriculture and public health. In general, the use of a policing approach with "confrontational tactics" seems to have been more common. ${ }^{97}$ In 1930, Appelman recommended a reward system to stimulate enforcement personnel, particularly forest police, to improve duty performance..$^{98}$ It is unclear whether his recommendation was actually implemented, but the problem persisted. Reports on the forest districts of Jember and Banyuwangi around the mid-1930s revealed that numerous offences continued to occur with authorities unable to act. ${ }^{99}$

It came as no surprise that the enforcement of conservation regulations was generally said to be poor and few results were achieved. The conservation authorities were said to have lacked awareness and technical knowledge on how to execute their tasks or how important their tasks were. ${ }^{100}$ Similar observations were made by G.F.H.W. Rengers Hora Siccama and R.T.A. Soeria Nataatmadja, members of the Volksraad and the Netherlands Indies Society for Nature Protection. In their views, a major weakness in the field of nature and wildlife protection was that the enforcement apparatus did not act firmly against the culprits. ${ }^{101}$ Enforcement against illegal hunting was said to have only been in name only. ${ }^{102}$ Illegal hunting and wood stealing appear to have been among the major environmental crimes, which the authorities found more difficult to prevent than other forms of offence such as illegal grazing and tuber roots collection. In the case of hunting, the difficulty stemmed primarily from the mobile nature of the activity, combined with the use of firearms and the collective dimension of the endeavour. Meanwhile, wood stealing was not easily prevented because such an offence was often also undertaken collectively. In many cases the lack of personnel and the fear of violent revenge made forest police either reluctant or unable to act firmly against the offenders. ${ }^{103}$

The enforcement problem was compounded by other factors. First, although many offences were reported, only a small number of cases was said to have been followed up with legal actions. Moreover, among the few cases legally processed, there were complaints the punishments imposed on culprits were too light. ${ }^{104}$ Such measures were deemed ineffective to prevent offences from being repeated either by the same culprits or other parties. Second,

97. Peluso 1992, p. 147; Manuputty 1953, p. 486.

98. Appelman 1931, pp. 86-87.

99. Voogd and Rengers Hora Siccama 1939, p. 80.

100. Groeneveldt 1937, p. 5.

101. Rengers Hora Siccama 1940, pp. 87-88.

102. V. d. V. 1941, p. 252.

103. Warno 1929, p. 132.

104. Voogd and Rengers Hora Siccama 1939, pp. 103-104. 
in the broader context of the colonial bureaucracy, not all state agencies demonstrated high appreciation of the value of nature and wildlife reserves. In 1936, for example, the Prison Service of the Home Affairs Department proposed the conversion of one fourth of the Nusa Barung reserve into a detention facility, as had happened to the island of Nusa Kambangan. ${ }^{105}$ Third, as the conservation responsibility involved both forest and civil officials, there were also problems of work regulations and work equipment. ${ }^{106}$ In the field, the relationship between forest police and civil officials from the district level downward was not always harmonious. There often were suspicions that village officials did nothing to prevent villagers from violating forest and conservation regulations, which led to appeals for a more intensive cooperation between the two parties. ${ }^{107}$

Aside from internal problems, serious external obstacles originated from society at large. Violations of the conservation regulations were common as reflected in the figures on forest offences. In 1926, Resident H.A. Voet reported that the number of forest offences was 1,173 in 1922, 1,025 in 1923, and 1,817 in $1924 .{ }^{108}$ Considering the problem of supervision, the actual number of offences must have been higher than reported. Especially during times of hardship, an increase in the number of offences often occurred as more people saw nature and game reserves as the easiest way of escaping subsistence crises. ${ }^{109}$ Unfortunately, there are no further details regarding the nature of the offences. Illegal hunting, timber stealing and forest clearing were among the most frequently mentioned cases, but other offences such as illegal grazing, forest burning, charcoal making, and tuber collection occurred as well. Illegal hunting was reported to have been rife in the Nusa Barung reserve, Baluran reserve, and also Purwo reserve, where cases of timber, bamboo, and rattan stealing were quite common also. ${ }^{110}$ One report revealed that the offences were mostly committed by locals, but some of them by Europeans, Chinese, and Japanese ${ }^{111}$ as well.

There were two major roots of violations of the conservation regulations. The first was linked to the fact that the populations of the region traditionally had access to forest resources. The inhabitants of Puger, for example, were reported to have traditionally undertaken collective deer hunting and other resource uses on the island. But such activities were banned by the colonial authorities and were considered illegal with the designation of Nusa Barung

105. Appelman and Rengers Hora Siccama 1939, p. 291.

106. Lught 1933, pp. 195-198.

107. Odang 1937, p. 123; Warno 1929, p. 132.

108. ANRI, MvO Besuki, Resident Voet, 1922-1925.

109. Odang 1937, p. 116.

110. Appelman 1939, p. 298; Soepandar 1941, p. 27; Leefmans 1932, p. 39.

111. Appelman and Rengers Hora Siccama 1939, p. 291 
Island as a nature reserve. ${ }^{12}$ The continuous hunting and resource use by the locals might have been in part an indication of rejection of colonial claims and of a continuing contest over resources. It did not necessarily mean that the culprits were always and only locals, poor villagers who were forced to commit crimes in order to survive. The fact that non-locals were also among the culprits might suggest another root of the offences, representing a new development which the colonial authorities tried to stop. Besides individual actions, it is likely that behind some offences there were well-organized professionals who manipulated local villagers and made a living through crime. The fact that part of the stolen items were sold outside Besuki might be seen as evidence of this: highly valued carving wood (sawo kecik) to Bali and charcoal to Surabaya. ${ }^{113}$

By the 1940s, following the Japanese invasion, the situation worsened. Instead of strictly enforcing conservation measures, the Japanese did the opposite. For the sake of meat procurement, the Japanese were reported to have shot around 10,000 deer in the Hyang Highlands. ${ }^{114}$ In other areas, as well, similar actions seem to have been carried out, especially in the Baluran game reserve. The consequence was a steep decline in game populations in the Baluran reserve, especially wild oxen and deer. ${ }^{115}$ For the sake of food production, extensive forest clearing also occurred, not only at the initiative of locals, but under government sponsorship as well. ${ }^{116}$ In Jember, Japanese authorities provided financial support amounting to $f 4,500$ and rewards were promised to those who worked hard on establishing agricultural fields. ${ }^{117}$ Even war detainees were employed for clearing. ${ }^{118}$ Many violations against conservation regulations continued in the late 1940s as practically no effective control was in force and this had deep repercussions throughout the following decades.

The core problems of conservation in the 1950s and 1960s broadly remained the same, but increased in scale and became more intense. Despite the enormous conservation tasks to perform, the available resources to carry out the jobs across the country remained the same or even declined. The lack of personnel was still a major obstacle. Although there is no data for Besuki, in general there was a wide gap between the available and the required number of personnel to handle conservation matters. Many more personnel were actually needed, but in 1955 there were only about 250 personnel employed on conservation tasks

\footnotetext{
112. Ibid., p. 290.

113. Appelman 1939, p. 298

114. De Voogd 1946, p. 53; Hoogerwerf 1946, p. 52; Pluygers 1952, p. 49.

115. Rappard 1949, p. 243; Effendi \& Santosa 1984/1985, p. 29.

116. Kartasubrata et al. 1986, p. 7.

117. Soeara Asia, 16 Dec. 1943.
}

118. Warta Besoeki Shuu, 20 Sept. 1944. 
throughout the whole of Indonesia. ${ }^{119}$ Since 1961 there have been attempts at overcoming the personnel deficit, including a wildlife course at the Forestry Police School in Salatiga, followed by nature conservation courses in the Forest School, Bogor (1963), and in the Academy of Agriculture in Bogor (1964), the Academy of Architecture and Landscaping in Jakarta (1964), and the College of Biology at Padjajaran University, Bandung (1965). ${ }^{120}$ Despite these efforts, the number of conservation personnel has remained in deficit. In 1971, the forestry personnel active in conservation numbered only 5 in the high ranks (30 were required), 50 in the middle ranks ( 250 were required), and 350 in the lower ranks (1,500 were required). ${ }^{121}$ More recently, the lack of personnel was still to blame for the failure to stop illegal hunting and timber stealing in the Nusa Barung nature reserve. ${ }^{122}$ The situation of the region's other reserves was not much different, and adding personnel has still been considered an important part of improvements. ${ }^{123}$

A closely related issue to lack of personnel is the budget. Adding staff was always hard due to the limited financial capacity of the Indonesian government in the 1950s and 1960s. The budget assigned to conservation matters appears to have been far from sufficient to regularly supervise the reserves, scattered widely across the country. In 1955, nature protection in Indonesia was described as encountering "chronic financial shortage."124 Under such circumstances, only a few reserves were well-managed, especially the Gede-Pangrango reserve (West Java). Many others, by contrast, were illfunded and in many cases were inadequately managed by the authorities. ${ }^{125}$ Appelman suggested that the problem of funds might be mitigated by collecting and assigning revenue - generated from hunting licenses, firearms fees, export and import taxes on various plant and animal products, and a few other sources - to nature protection rather than using it for other purposes. ${ }^{126}$ There was dissatisfaction about the fact that the collection of revenue from reserves was under the control of the Department of Home Affairs and also the Police, while the Forest Service (Department of Agriculture and Agrarian Affairs) bore the management tasks and their incurred costs. ${ }^{127}$

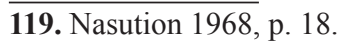

120. Taman 1968, p. 235.

121. Nasution and Taruminkeng 1971, pp. 148-151.

122. Kadri et al. 1981/1982, p. 41.

123. Beudels and Kurnianto 1982, p. 29.

124. Appelman 1955, p. 232.

125. Went 1945, p. 403; Hoogerwerf 1954, p. 197.

126. Appelman 1955, p. 232.

127. Satmoko 1955, p. 200. 
In the 1950s, Hoogerwerf lamented that the bureaucrats in charge of conservation regulation enforcement often had little knowledge or a poor appreciation of the values of nature conservation, and were inclined to ignore violations. ${ }^{128}$ In the $1950 \mathrm{~s}$, in Besuki, for example, a mantri managing the Gintingan forest of Jember illegally leased forest plots for agriculture and wood extraction. ${ }^{129} \mathrm{~A}$ further obstacle was the fact that even within the Forestry Service there was a battle of interests. A big blow hit the conservationists in 1954, with a withdrawal of about 20,000 hectares from the Purwo wildlife reserve and its conversion into a commercial forest, producing teak and mahogany. This development seriously debilitated the reserve's role in preserving large mammals because the excised area was in fact open terrain, an essential part of their living habitat. ${ }^{130}$ Full support was not always obtained from other state bodies. In the Baluran wildlife reserve in the 1960s, violations against the conservation regulations were in fact also committed by the armed forces in the form of hunting and conversion of part of the reserve into a military training centre. ${ }^{131}$

But serious obstacles also emerged from society at large, as a result of the contest over resources, especially between state agencies and the people when conservation measures were in force. In Jember, a conservation plan in 1951 for afforestation of 500 hectares of cleared forest lands situated in Silo-Mandiku, which was expected to reduce flood threats in the Mayang and Wirolegi areas, led to a conflict between the Forestry Service and the farmers who had been exploiting the area since the Japanese occupation. ${ }^{132}$ The Forestry Service was also in conflict with farmers occupying 34 hectares of land in Puger. ${ }^{133}$ In Pasanggaran (Banyuwangi Regency), afforestation measures by the Forestry Service were also opposed by farmers of Kesilir village. ${ }^{134}$ No further details regarding these cases are available, but it is certain that the contest over resources made reforestation measures hard to carry out without compromises and time-consuming negotiations. Tensions emerged when the Forestry Service demanded the return of 296 hectares of the former Pringgodani forest located in Alasbuluh, which was to be reforested. Only through a series of negotiations could the conflict eventually be settled. The farmers agreed to return the lands in exchange for the Forestry Service's willingness to cede 50 hectares for their interests. ${ }^{135}$

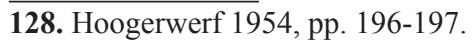

129. Trompet Masjarakat, 11 Oct. 1957.

130. Beudels and Kurnianto, 1982, pp. 4-5.

131. Sedhana 1982, p. 22.

132. Trompet Masjarakat, 9 June 1951.

133. Trompet Masjarakat, 2 Oct. 1953.

134. Trompet Masjarakat, 24 March 1954.

135. Trompet Masjarakat, 4 Aug. 1958. 
While conflicts over forest lands in several places were gradually solved, encroachments on the nature and wildlife reserves continued unabated, stimulated by rising demographic pressures and limited employment opportunities. As partly indicated by recent observations, in Baluran the offences took on a variety of forms, such as timber stealing and collection of other forest products, livestock grazing, setting of fires, and temporary settlement construction by milkfish fry poachers. ${ }^{136}$ The other reserves, too, suffered more or less from the same forms of illegal activities. If more recent observations are any indication, in the Meru Betiri area, cases of timber, bamboo and rattan stealing, sugar-palm tapping, and swidden farming by the nearby villagers have also been common. In particular, parts of the conservation areas next to settlements have been reported to have been seriously damaged, and together with estates, the adjacent settlements have continued to exert enormous pressure on the reserves. ${ }^{137}$

The Indonesian government certainly did not turn a blind eye to the problems. Especially from the late 1960s onward, the government displayed a more serious attitude to nature conservation. At the macro level, a bigger budget was allocated to improve nature-protection management, from around US \$27,000 in 1969 to US \$250,000 in $1970 .{ }^{138}$ In Besuki, this positive attitude was reflected by the decision made in 1968 to transfer the area previously withdrawn from the South Banyuwangi reserve used for commercial forest from Perhutani to the Direktorat PPA. ${ }^{139}$ Unlike how bringing the area back for conservation functions on paper, doing this in the field seems to have been difficult to achieve and consumed more time for enforcement for several reasons, especially technical details regarding the existing commercial forest and the workers employed for its establishment. ${ }^{140}$ But the fact that this agreement was made at all was a landmark, reflecting stronger interest in conservation matters. At around the same time, government-financed afforestation was also carried out. The regent of Jember claimed in 1973 that around 4,100 hectares of degraded areas had been reforested. ${ }^{141}$ Commission IV of the People's Representative Council also indicated it had fulfilled the 1970/1971 afforestation target in East Java, reaching 21,000 hectares. ${ }^{142}$

\footnotetext{
136. Siswanto 1959, pp. 21-22.

137. Daryadi et al. 1979, pp. 26-27.

138. Boer et al. 1978, p. 149.

139. Beudels and Kurnianto 1982, pp. 5, 13.

140. Handojono 1974, p. 28.

141. Hadi 1973, Appendix 1.

142. Sekretariat DPR 1972, p. 4.
} 


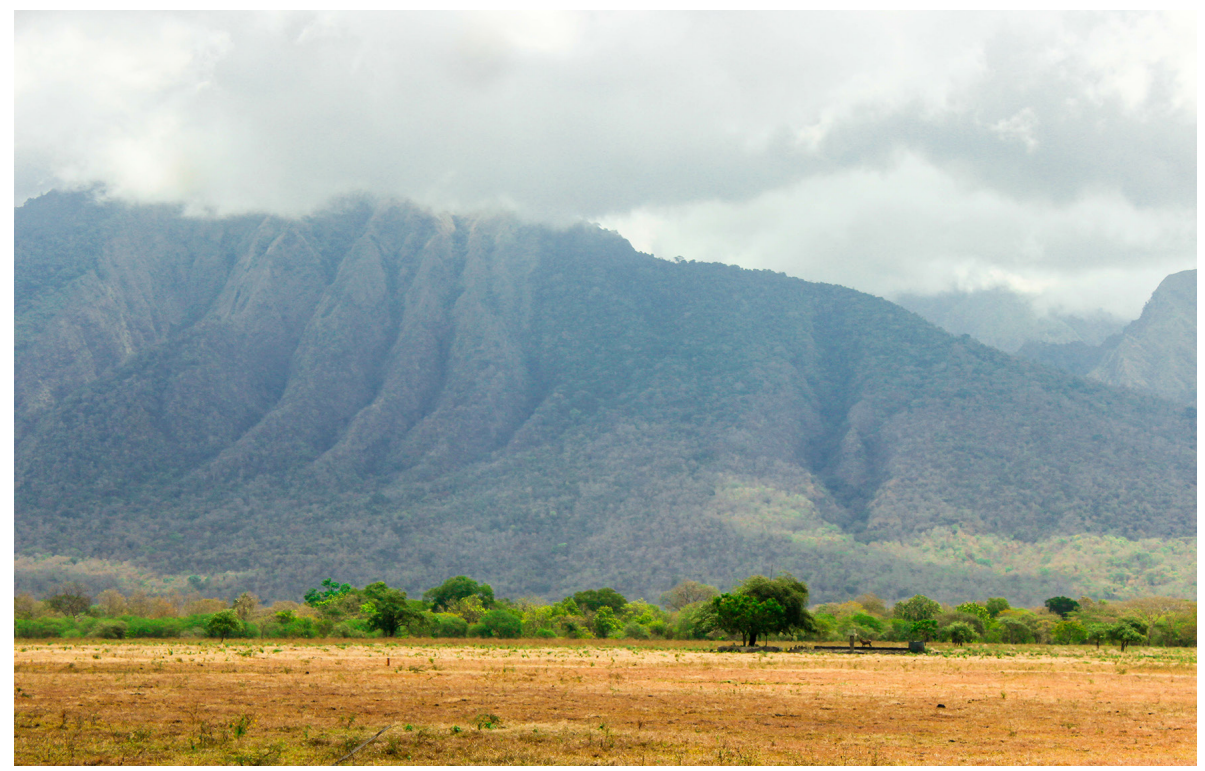

Fig. 7 - Baluran Nature Reserve (Photog.: Nawiyanto 2018)

Appeals and support from international organisations, especially the World Wildlife Fund (WWF) and the UNDP/FAO, contributed significantly to the changing attitude of the government towards nature conservation. From 1965 the WWF was already active in Indonesia and granted financial assistance to carry out conservation activities, mostly in the Ujungkulon reserve (West Java). In 1968 the WWF also provided financial support to improve the management of the Baluran game reserve. ${ }^{143}$

Given the enormous challenges to bring about improvements, in his official visit in 1971, the WWF president directly urged President Soeharto to personally issue a statement expressing his strong concerns with flora and fauna protection to all authorities within the bureaucracy, from the Minister of Agriculture down to the regent (bupati) ${ }^{144}$ In the 1970s, a number of conservation projects were undertaken. The Meru Betiri reserve became a WWF project in 1973, designed especially to save the endangered Javan tiger. ${ }^{145}$ With a donation of US $\$ 22,130$ the Meru Betiri conservation project was part of the WWF international programme broadly called "Operation Tiger," which had also been undertaken elsewhere in Asia, particularly in India. ${ }^{146}$

143. Treep 1974, pp. 59-60.

144. Ibid., pp. 64-65.

145. Seidensticker and Suyono 1980.

146. Treep 1974, pp. 59-60. 


\section{Conclusion}

Conservation politics were not something new to post-1970 Indonesia, and Besuki was an important element of colonial and post-colonial conservation politics. Besuki had the largest and greatest number of nature and game reserves in Java. The reasons for this were in part its position as a frontier region and its later socio-economic development compared with many other areas of Java. But the region's conservation politics were hardly unique. What happened in Besuki was a reflection of trends and processes taking place in a broader context. As elsewhere in Java, Besuki experienced the broadening conservation movement from hydrology- and soil-linked conservation for the sake of agriculture to aesthetic- and scientific-linked conservation, speaking on behalf of nature and future generations. The legal framework and measures regarding conservation put in place in Besuki were greatly credited to the colonial conservationists affiliated with the Netherlands Indies Society for Nature Protection and from a long term perspective, nature protection in Besuki clearly suggested strong colonial origins.

In the two periods, the primary problems for nature protection lay mostly in enforcement, rather than in the legal framework. A significant attempt was made by colonial authorities to improve conservation regulations. But lack of budget and qualified personnel posed serious obstacles to the enforcement of conservation regulations. Moreover, within the colonial government itself, contests over resource use were also present. Independence did little to solve the problems and the situation even worsened as illustrated by the removal of an extensive part of the Purwo and Jati-Ikan reserves to become commercial forests in the early 1950s. Another setback was reflected in the conversion of part of the Baluran game reserve into a military training area, and the involvement of some state officials in violations of conservation regulations.

Externally, the conservation regulations and measures also faced a significant challenge. Part of the challenge arose from the longstanding traditional activities linked to forest land and forest resource use, which continued to take place despite the fact they were banned under conservation regulations. Another challenge emerged from a group of individuals making a living through crimes, partly through cooperation with the local people. The fact that conservation measures often restricted direct advantages traditionally enjoyed by locals, helped to explain the unpopularity of conservation issues among Indonesians. Unsurprisingly, both the nationalist movement during colonial times and the mass-based political parties in post-colonial times hardly used nature conservation issues in their struggle. This reality also explained why, until around 1970, nature conservation in Besuki and elsewhere in colonial and post-colonial Indonesia remained very much part of government circles, state-centred, and with a stronger international thrust, rather than relying on popular support. Only from the mid-1970s did the role of non-governmental 
organizations and media groups in conservation begin to grow. This is another direction for further research.

\section{References}

\section{Archives}

ANRI (Arsip Nasional Republik Indonesia), Jakarta, Archief van Algemeene Secretarie 19181920, abbreviated as AlgSec; Memorie van Overgave Resident Besoeki 1918-1938, abbreviated as $M v O$ Besuki.

\section{Unpublished papers, reports}

Hadi, Abdul, 1973. "Gelora pembangunan daerah kabupaten Jember," Paper. Jakarta: Departemen Dalam Negeri.

Beudels, R.C. and Kurnianto, 1982. "Blambangan nature reserve management plan," Field Report (40). Bogor: UNDP/FAO National Parks Development Project.

De Boer, I.J., N.A. Joncheere, C.S. van Beunigen, and J.M.A. van de Velde, 1978. Report on a Study-Tour on Nature Conservation in Iran, India, Thailand, Malaysia and Indonesia. Wageningen: Department of Nature Conservation and Wildlife Management, Agricultural University of Wageningen.

Daryadi, Lukito, et al., 1979. "Laporan Survai Inventarisasi dan Identifikasi Flora di Suaka Margasatwa Meru Betiri Jawa Timur," Research Report. Bogor: Direktorat Perlindungan dan Pengawetan Alam.

Departemen Kehutanan, 1985; "Penilaian potensi zona penyangga taman nasional Meru Betiri. Research Report," Jember: Sub Balai Perlindungan dan Pelestarian Alam Jawa Timur II.

Effendi, Sulaiman and Yanto Santosa, 1985/1986. "Sistem pembinaan habitat banteng di taman nasional Baluran," Research Report. Jakarta: Direktorat Jenderal Perlindungan Hutan dan Pelestarian Alam, Departemen Kehutanan.

Handojono, Sudarto, 1974. "Suaka margasatwa Meru-Betiri," Survey Report. Bandung: Lembaga Ekologi Universitas Padjajaran.

Kadri, Wartono, et al. 1981/1982. "Laporan Survai Inventarisasi Fauna di Cagar Alam Pulau Nusa Barung di Kecamatan Puger Kabupaten Jember Propinsi Jawa Timur," Research Report. Bogor: Direktorat Perlindungan dan Pengawetan Alam.

Sastrawidjaja, Kosasih, et al., 1986. "Laporan penilaian potensi cagar alam pulau Nusa Barong," Research Report. Malang: Balai Konservasi Sumber Daya Alam IV.

Sedhana, Made, 1982. "Kondisi ekologik taman nasional Baluran," Research Report. Jember: Fakultas Pertanian Universitas Jember.

Sinaga, Walman, 1970. "Suaka margasatwa Baluran,” Research Paper. Bogor: Direktorat Pembinaan Hutan Dinas Perlindungan dan Pengawetan Alam.

\section{Publications}

Anonim, 1931. "Debat over prae-advies Ir. F.J. Appelman,” Tectona 24, pp. 469-487.

ANRI, 1978. Memori serah jabatan 1921-1930 (Jawa Timur dan Tanah Kerajaan). Jakarta: Penerbitan Sumber-sumber Sejarah No. 10.

Appelman, F.J., 1931. "De Taak van den boschbeheerder ten aanzien van de bescherming van het wild," Tectona 25, pp. 77-87.

Appelman, F.J., 1937. "De Baloeran," In: Album van Natuurmonumenten in NederlandschIndië," in C.G.G.J. van Steenis (ed.), 3 jaren Indisch natuur leven. Batavia: NederlandschIndische Vereeniging tot Natuurbescherming, pp. 49-56. 
Appelman, F.J., 1939. "Het schiereiland Poerwo: bosch en wild in Java's zuidoost-hoek," in C.G.G.J. van Steenis (ed.), 3 jaren Indisch natuur leven. Batavia: Nederlandsch-Indische Vereeniging tot Natuurbescherming, pp. 293-298.

Appelman, F.J. 1955. "Natuurbescherming," Tectona 43, pp. 218-219.

Appelman, F.J. and F.H. Endert, 1936. "Voornaamste wettelijke bepalingen inzake: dierenbescherming, jacht, en natuurmonumenten en wildreservaten," Natuur Bescherming in Indie gedurende het jaar 1935: tiende verslag van de Nederlandsch Indische vereeniging tot natuurbescherming. Buitenzorg: Archipel.

Appelman F.J. and G.F.H.W. Rengers Hora Siccama, 1939. "Noesa Baroeng: Natuurmonument tegenover Besoeki's Zuidkust," in C.G.G.J. van Steenis (ed.), 3 jaren Indisch natuur leven. Batavia: Nederlandsch-Indische Vereeniging tot Natuurbescherming, pp. 289-292.

Arnscheidt, J., 2009. Debating Nature Conservation: Policy, Law, and Practice in Indonesia. Leiden: Leiden University Press.

Berczy, L., 1941. “Adjaks,” De Nederlandsch Indische Jager 11(10), p. 243.

Boomgaard, P., 1996. Changing Economy in Indonesia, Forest and Forestry 1823-1941. Amsterdam: Royal Tropical Institute.

Boomgaard, P., 1999. "Oriental Nature, its Friends and its Enemies: Conservation of Nature in Late-Colonial Indonesia," Environment and History 5(3), pp. 257-292.

Boomgaard, P. and A.J. Gooszen, 1991. Changing Economy in Indonesia, Vol. 11: Population Trends 1795-1942. Amsterdam: Royal Tropical Institute.

Broersma, R., 1912. Besoeki: Een Gewest in opkomst. Amsterdam: Scheltema and Holkema.

Broersma, R., 1937. "Vijf en twintig jaar natuurbescherming in Indië," Koloniaal Tijdschrift 26 , pp. 226-232.

Clemens, A., J. Th. Lindblad, and J. Touwen, 1992. Changing Economy in Indonesia, Vol. 12b: Regional Patterns in Foreign Trade 1911-1940. Amsterdam: Royal Tropical Institute.

Coomans de Ruiter, L., 1948-1949. "Natuurbescherming in Nederlandsch-Indië," Indonesië 2, pp. 140-162.

Cortesão, A. 1967. The Suma Oriental of Tomé Pires and the Book of Francisco Rodrigues. Nendeln: Kraus Reprint, 2 vols.

Cribb, R., 1988. "The Politics of Environmental Protection in Indonesia," Working Paper No. 48. Clayton: Centre of Southeast Asian Studies, Monash University.

Cribb, R., 1997. "Birds of Paradise and Environmental Politics in Colonial Indonesia, 18901931," in P. Boomgaard, F. Colombijn and D. Henley (ed.), Paper Landscapes: Explorations in the Environmental History of Indonesia. Leiden: KITLV Press, p. 379-408.

Cribb, R., 2000. Historical Atlas of Indonesia. Singapore: New Asian Library.

Dammerman, K.W., 1929. Preservation of wild life and nature reserves in the Netherlands Indies. Weltevreden: Emmink.

Donner, W., 1987. Land use and environment in Indonesia. London: C. Hurst.

Eshuis, W., 1939; "Protection of wild life in the Netherlands Indies," Bulletin of the Colonial Institute of Amsterdam 4, pp. 201-207.

Franck, P.F., 1937. "Het Hiang-plateau als natuurreservaat. In: Album van Natuurmonumenten in Nederlandsch-Indie,," in C.G.G.J. van Steenis (ed.), 3 jaren Indisch natuur leven. Batavia: Nederlandsch-Indische Vereeniging tot Natuurbescherming, pp. 33-41.

Van Goor, C.P. et al., 1982. Indonesian Forestry Abstracts: Dutch Literature until about 1960. Wageningen: Centre for Agricultural Publishing and Documentation.

Groeneveldt, W., 1937. De Natuurbescherming in Nederlandsch-Indië. Batavia: De Unie.

Groneman, I., 1902. Op het Jang Gebergte in Oost Java. Zutphen: W.J. Thieme \& Cie.

Grove, R.H., 1995. Green imperialism: colonial expansion, tropical island Edens and the origins of environmentalism, 1600-1860. Cambridge: Cambridge University Press. 
Grove, R.H., V. Damodaran, and S. Sangwan, 1998. "Introduction," in R.H. Grove, V. Damodaran, and S. Sangwan (ed.), Nature and the Orient: Environmental History of South and Southeast Asia. Delhi: Oxford University Press, pp. 1-26.

Groves, C.P., 1977. "Wildlife Reserves in Indonesia," Indonesia Circle 14, pp. 13-20.

Hageman, J., 1868. “Over het Rijzen der Kusten van Oostelijk Java en Madoera," Natuurkundige Tijdschrift voor Nederlandsch-Indië 30, pp. 248-284.

Holle, K.F., 1866. "Een groot gevaar dat sluipend nadert," Tijdschrift voor Nijverheid en Landbouw in Nederlandsch Indie 12, pp. 122-131.

Hoogerwerf, A., 1946. "Game and Nature Protection," Natuurwetenschappelijk Tijdschrift voor Nederlandsch Indië 102(3), p. 52.

Hoogerwerf, A., 1948. "Het wildreservaat Baloeran," Tectona 38, pp. 33-49.

Hoogerwerf, A., 1953. "Perlindungan alam dan pemburuan di Indonesia," Almanak Pertanian. Djakarta: Badan Usaha Penerbit Almanak Pertanian.

Hoogerwerf, A., 1954. "Perlindungan alam dan pemburuan di Indonesia," Almanak Pertanian. Djakarta: Badan Usaha Penerbit Almanak Pertanian.

Hoogerwerf, A., 1974. "Report on a Visit to Wildlife Reserves in East Java, Indonesia (August to November 1971)," Medededelingen (21). Austerlitz: Netherlands Commission for International Nature Protection, pp. 1-51.

Hoogerwerf, W. and C.G.G.J. van Steenis, 1936. "Berichtgeving omtrent Natuurbescherming in 1935," in Natuur Bescherming in Indie gedurende het jaar 1935: tiende verslag van de Nederlandsch Indische vereeniging tot natuurbescherming. Buitenzorg: Archipel, pp. 4-104.

Hutabarat, A.A., 1972. "Suaka alam dan pembinaannya," Gema Perhutani 41(11-12), pp. 10-16. Kartasubrata, et al., 1986. Sejarah kehutanan Indonesia. Jakarta: Departemen Kehutanan.

Kiès, C.H.M.H., 1936. "Nature Protection in the Netherlands Indies," Special Publication (8). Cambridge: American Committee for International Wild Life Protection.

Koning, J., 1928. "Na Vijftig Jaren Tropenarbeid: een Gemoedelijk Praatje met een Gemoedelijk Man," Eigen Haard 54(6), pp. 104-106.

Lam, H.J., 1923. "Verslag van den 1sten Secretaris Nederl. Indische Vereeniging tot Natuurbescherming," Verslag over 1920-1922. Buitenzorg: Archipel.

Ledeboer, A.J.M., 1934. Natuurbescherming door particulieren, het Jang-plateau Oost-Java Nederlandsch-Indië. s.l.: s.n.

Leefmans, S., 1932. "Verslag der Jaarvergadering op 29 Maart 1931 Nederlandsch Indische Vereeniging tot Natuurbescherming," Verslag over de jaren 1929-1931. Buitenzorg: Archipel.

Lombard, D., 1983. "Pandangan Masyarakat Jawa Terhadap Hutan," in M. Bonneff et al., Citra Masyarakat Indonesia. Jakarta: Sinar Harapan, p. 262-278.

Lombard, D., 1996. Nusa Jawa Silang Budaya, Vol. 3: Warisan Kerajaan-kerajaan Konsentris. Jakarta: Gramedia.

Lught, C.S., 1933. "De natuurbescherming in Nederlandsch-Indië," Tectona 26, p. 186-198.

MacKinnon, K., 1986. Alam Asli Indonesia: Flora, Fauna, dan Keserasian. Jakarta: PT Gramedia.

Manuputty, 1953. "Pemakaian tanah yang tidak syah dalam hutan2 di Djawa," Rimba Indonesia 2(10-12), pp. 485-489.

De Meyier, J.E., 1903. "Het boschwezen en de Politie," De Indische Gids 25(1), pp. 709-715.

Mo, T.T., 1957. "Kebuasan manusia terhadap binatang liar harus dihentikan," Rimba Indonesia 6(3-5), pp 107-176.

Myers, R., and Mumu Muhajir, 2015. "Searching for Justice: Rights vs 'Benefits' in Bukit Baka Bukit Raya National Park, Indonesia,” Conservation and Society 13(4), pp. 370-381. 
Nasution, Hasan Basjarudin, 1968. "Recent Development in the Field of National Park, Nature Reserve and Natural Areas," Rimba Indonesia 13(1-4), pp. 12-29.

Nasution, Hasan Basjarudin 1971. "Perlindungan alam dan pembinaan margasatwa suaka alam dan hutan wisata," Warta Pertanian 12, pp. 4-8.

Nasution, Hasan Basjarudin and T.C. Taruminkeng, 1971. "Nature Conservation Education in Indonesia," IUCN Publication 20, pp. 148-151.

Odang, R., 1937. "Iets over boschpolitie," Het Bosch 4, pp. 115-123.

OMV, 1908. Onderzoek naar de mindere welvaart der inlandsche bevolking op Java en Madoera, Vol. 7 (14): samentrekking van de afdeelingsverslagen over de uitkomsten der onderzoekingen naar de Irrigatie in de residentie Besoeki. Batavia: Albrecht.

Peluso, Nancy-Lee, 1992. Rich forests, poor people: resource control and resistance in Java. Berkeley: University of California Press.

Piepers, M.C., 1896. "Door welke maatregelen kan tot eene rationeele bescherming der inheemsche dieren-en plantenwereld in Nederlandsch Indië worden gekomen?," Tijdschrift voor Nederlandsch Indië 25(1), pp. 38-72.

Pluygers, L.A., 1952, Natuurbescherming en wildbeheer, special met betrekking tot Indonesië. Djakarta: B. Wolters.

Poerwokoesoemo, Soepardi, 1956. Jati Jawa (Tectona grandis Linn.). Jakarta: No publisher.

Potter, L., 2003. "Forests versus Agriculture: Colonial Forest Services, Environmental Ideas and the Regulation of Land-Use Change in Southeast Asia," in L. Tuck-Po, W. de Jong, and A. Ken-ichi (ed.), The political ecology of tropical forests in Southeast Asia: historical perspective. Kyoto: Kyoto University, pp. 29-71.

Rappard, F.W., 1949. "Verband in een Oost-Javaanse Bantengkunde," Chronica Naturae 105 (10), pp. 243-247.

Rengers Hora Siccama, G.F.H.W., 1940. "Berichtgeving omtrent Natuurbescherming over 1936-1938: Onderwerpen van Algemeen Aard," Het Bosch 7(1), pp. 84-98.

Ricklefs, M.C., 1998. The Seen and Unseen Worlds in Java, 1726-1749. St. Leonards: Allen and Unwin.

Sandbergen, F.J.W.H., 1932. "Natuurbescherming," Koloniaal Tijdschrift 21, pp. 433-459.

Santoso, Trio et al., n.d., Buku informasi kawasan konservasi Balai Konservasi Sumber Daya Alam Jawa Timur II. Jember: Balai Konservasi Sumber Daya Alam Jawa Timur II.

Satmoko, Koesnadi P., 1953. “Arti perburuan sekarang,” Rimba Indonesia 2(10-12), pp. 405-412.

Satmoko, Koesnadi P., 1955. "Tugas Perlindungan Alam/Margasatwa Djawatan Kehutanan," Rimba Indonesia 4(3-5), pp. 405-412.

Schuitemaker, J.P., 1950. Bos and bosbeheer in Java. Djakarta: Groningen.

Schulze, L.F.M., 1890. Fuhrer auf Java: Ein Handbuch fur Reisende. Leipzig: Grieben's Verlag.

Seidensticker, J. and Suyono, 1980. The Javan tiger and the Meru Betiri reserve: A plan for management. Gland: International Union for Conservation of Nature and Natural Resources.

Sekretariat DPR. 1972. Laporan penindjauan komisi IV (departemen pertanian, departemen tenaga kerdja, dan departemen transmigrasi dan koperasi.) D.P.R.-R.I. pada masa reses persidangan ke-III tahun sidang 1971-1972. Djakarta: Sekretariat DPR Republik Indonesia.

Setijodiwirijo, Koesnoto, 1957. "Masalah perlindungan alam di Indonesia," Insinjur Indonesia 4(17-18), pp. 4-12.

Siburian, Robert, 2008. "Taman Nasional Kuai dan Perebutan Sumberdaya Alam," Jurnal Masyarakat dan Budaya 10(2), pp. 89-116.

Siburian, Robert, 2010. "Pengelolaan Taman Nasional Bantimurung-Bulusarung dan Dampaknya Terhadap Masyarakat Lokal," Jurnal Masyarakat dan Budaya 12(1), pp. 119-144.

Siswanto, 1959. "Nener dan suaka margasatwa," Berita Perikanan 11(2), pp. 21-22. 
Situmorang, Abdul Wahib, 2013. Dinamika Protes Kolektif Lingkungan Hidup di Indonesia 1968-2011. Yogyakarta: Pustaka Pelajar.

Smiet, A.C., 1990. "Forest Ecology on Java: Conversion and Usage in a Historical Perspective," Journal of Tropical Forest Science 2(4), pp. 286-302.

Smiet, F., 1987. "Tropical Watershed Forestry under Attack," Ambio 16(2-3), pp. 156-157.

Soepandar, 1941. "Een banteng onder de rook van Banjoewangi," Het Bosch 8(1), pp. 25-27.

Sri Margana, 2012. Perebutan Hegemoni Blambangan: Ujung Timur Jawa 1763-1813. Yogyakarta: Pustaka Ifada.

Van Steenis, C.G.G.J., 1939. "Natuurbescherming in Netherlands-Indië van botanist standpunt," Natuurkundig Tijdschrift voor Nederlandsch-Indië 99, pp. 148-163.

Van Steenis, C.G.G.J., 1972. The mountain flora of Java. Leiden: E.J. Brill.

Talbot, L.M., and M.H. Talbot, 1968. Editors' introduction. IUCN Publications New Series (10), pp. 15-17.

Taman, I.M., 1968. "Training for Effective Careers in Conservation in Indonesia," IUCN Publications New Series 10, pp 235-236.

Ted, 1974. “Dimana engkau banteng,” Gema Perhutani Special Edition, pp. 94-98.

Treep, L., 1974. "On the tiger in Indonesia (with special reference to its status and conservation)," A.L.H. Report (164). Wageningen: Department of Nature Conservation and nature Management, Agricultural University.

V. d. V. 1941. "Onbezoldigde politie-ambtenaren," De Nederlandsch Indische Jager 11(12), p. 252.

Van Vuuren, L., 1929. "Geographical Aspect of the Netherlands East Indies," in L.M.R. Rutten (ed.), Science in the Netherlands East Indies. Amsterdam: De Bussy, pp. 1-37.

Veth, P.J., 1903. Java: Geographisch, Etnologisch, Historisch, Vol. 3. Haarlem: Bohn.

De Voogd, C.N.A., 1946. "Rechtlijnen voor een Doeltreffende Jachtregeling en Natuurbescherming in Nederlands-Indië," Tectona 36, pp. 41-58.

De Voogd, C.N.A., and G.F.H.W. Rengers Hora Siccama, 1939. "Onderwerpen van Lokalen Aard: Residentiegewijs Gerangschikt," in C.G.G.J. van Steenis (ed.), 3 jaren Indisch natuur leven. Batavia: Nederlandsch-Indische Vereeniging tot Natuurbescherming, pp. 49-154.

Van der Wal, S.L. (ed.), 2001. Kenang-kenangan pangreh praja Belanda 1920-1942. Jakarta: Jambatan and Perwakilan KITLV.

Warno, 1929. "Perloe diketahoei (bagi kita polisi hoetan)," Soeara Boschwezen 6(5-6), pp. 131-132.

Went, F.W., 1945. "The Tjibodas Biological Station and Forest Reserve, a Naturalist Paradise," in Pieter Honig and Frans Verdoorn (ed.), Science and Scientists in the Netherlands Indies. New York City: Board for the Netherlands Indies, Surinam and Curaçao, p. 403.

Westermann, J.H., 1945. "Wild Life Conservation in the Netherlands Empire, its National and International Aspects," in Pieter Honig and Frans Verdoorn (ed.), Science and Scientists in the Netherlands Indies, New York City, Board for the Netherlands Indies, Surinam and Curaçao, pp. 417-424.

Whitten, T., R.E. Soeriaatmadja, and S.A. Afiff, 1996. The Ecology of Java and Bali. Singapore: Periplus Editions.

Wijnmaalen, H.J., 2001. “Ambtenar BB di Jawa Timur, 1926-1932,” in S.L van der Wal (ed.), Kenang-kenangan Pangrehpraja Belanda, 1920-1942. Jakarta: Perwakilan KITLV and Djambatan, pp. 190-214.

Yudistira, Pandji, 2014. Sang Pelopor: Peranan Dr SH Koorders dalam Sejarah Perlindungan Alam di Indonesia. Jakarta: Direktorat Kawasan Konservasi dan Bina Hutan Lindung Kementerian Kehutanan.

Yuwono, Harto, 2013. Sejarah Konservasi Alam di Indonesia. Kapuas: Balai Taman Nasional Danau Sentarum. 